\title{
Implications of 'Lock-in' on Public Sector Project Management in a Small Island Development State
}

\author{
Aaron Anil Chadee ${ }^{1, *(\mathbb{C}}$, Xsitaaz Twinkle Chadee ${ }^{2}\left(\mathbb{D}\right.$, Abrahams Mwasha $^{1}$ and Hector Hugh Martin ${ }^{3} \mathbb{C}$ \\ 1 Department of Civil and Environmental Engineering, The University of the West Indies, \\ St Augustine 330110, Trinidad and Tobago; Abrahams.Mwasha@sta.uwi.edu \\ 2 Department of Physics, The University of the West Indies, St Augustine 330110, Trinidad and Tobago; \\ Xsitaaz.Chadee@sta.uwi.edu \\ 3 School of Civil Engineering and Built Environment, Liverpool John Moores University, Liverpool 72046, UK \\ H.H.Martin@ljmu.ac.uk \\ * Correspondence: aaronchadee@hotmail.com;
}

Citation: Chadee, A.A.; Chadee, X.T.;

Mwasha, A.; Martin, H.H.

Implications of 'Lock-in' on Public

Sector Project Management in a Small Island Development State. Buildings 2021, 11, 198. https://doi.org/

10.3390/buildings11050198
Jurgita Antucheviciene

Received: 24 March 2021

Accepted: 4 May 2021

Published: 8 May 2021

Publisher's Note: MDPI stays neutral with regard to jurisdictional claims in published maps and institutional affiliations.

Copyright: (c) 2021 by the authors. Licensee MDPI, Basel, Switzerland. This article is an open access article distributed under the terms and conditions of the Creative Commons Attribution (CC BY) license (https:// creativecommons.org/licenses/by/ $4.0 /)$.

\begin{abstract}
The concept of 'Lock-In', or the escalating cost of overcommitment on a project to a failing course of action, has unforeseeable implications in project management. This paper presents a case study on the occurrence and consequences of lock-in within the context of public sector housing projects in a small island developing state (SIDS). It demonstrates that cost overruns continue beyond the commissioning phase and throughout the project's lifecycle, even though technical contingencies were implemented to deliver the intended project benefits. The findings unpack the implications of political expediency as a strategic tool mobilised to supersede proper technical decision-making prior to project execution. It concludes that project practitioners' commitment to select and continue with a sub-optimal project can lead to the implementation of ineffective solutions to justify their actions, resulting in failed outcomes with negative social consequences. This research helps to advance project management knowledge in the us-er/operation phase, because previous scholarly work was limited to investigating lock-in from project conceptualisation to the commissioning phase.
\end{abstract}

Keywords: cost overruns; political influences; root causes; public housing programmes; small island developing states

\section{Introduction}

Social infrastructure development projects (SIDPs), such as public housing, often begin with noble intentions of delivering beneficial outcomes to society. The utility derived from low-income housing delivery has proven to be advantageous, positively influencing social dynamism and affecting economic growth [1]. However, these social infrastructure projects are delicate. The reversal of derived benefits can easily fester, and the intended community absorbs a consequential shortfall of benefits. Through ill-conceived initiatives, such social projects fall short of baselined project metrics such as time, cost, and quality. Furthermore, compromise on the realisation of intended benefits occurs during delivery [2]. As population growth continues, the demand for public housing is ever-increasing, and the optimisation of public funds expenditure to serve the larger public is warranted [3].

In small island developing states (SIDS), the shortfall in social infrastructure benefits is magnified [4]. SIDS became prominent during the 1992 Earth Summit held by the United Nations (UN) in Brazil. SIDS comprise 58 small island countries, of which 38 are UN member states, from three geographic regions, namely, the Caribbean, the Pacific, and the Atlantic, Indian Ocean, and South China Sea (AIS) [5]. The UN described SIDS as small, low-lying, developing countries with fragile environments and high susceptibility to the impacts of climate change and other natural disasters [6]. The dependency on international trade (and aid) and their inability to benefit from economies of scale due to small land masses and populations open additional vulnerabilities to economic shocks. 
Their remoteness and limited resources attract a higher cost for installing infrastructure, communication, and transportation services $[4,6,7]$.

In the Caribbean, some SIDS have urbanisation rates exceeding 70\%: Trinidad and Tobago is projected at $72 \%$, Suriname at $76 \%$, and the Bahamas at $79 \%[5,8]$. To satisfy the relatively high urbanisation levels, particularly in Trinidad and Tobago, and to mitigate the high construction costs for living accommodations, the state undertakes public housing initiatives to provide housing and associated infrastructure at subsidised costs to potential beneficiaries [9]. Notwithstanding the implementation of systems and processes to manage the construction of these projects, recurrent issues of cost overruns and delays manifest at a high rate [2]. The management of cost overruns on infrastructure development projects in SIDS is an ever-challenging task and has a direct negative impact on these small economies. Cost overruns are withdrawn from budgets for other important and viable social projects which are subsequently constrained by inadequate funding [10]. This results in an increased cost of completing SDIPs and impedes the overall planned development policies and initiatives of SIDS.

Thus, to gain a deeper understanding of the cost overrun phenomena, a focused and narrow research approach is warranted to unpack the causal nature of cost overruns based on a particular theory and trace its influence within a specific scenario and context. This paper presents the concept of 'Lock-In', or the escalating cost of overcommitment on a project to a failing course of action [11] on construction management decision-making and practices. Previous studies on lock-in have shown that cost overruns based on an overcommitment to an ineffective decision stop at project commissioning [12]. The majority of research on lock-in applies to developed countries [12-14]. This study attempts to narrow the existing theoretical gap by proposing that the impact of lock-in materialises as cost overruns and continues beyond the execution and commissioning phases, throughout the project life cycle. From the authors' investigations, this is a unique undertaking that expands the theoretical basis of cost overruns.

This research was a single critical case study to analyse the series of events through process-tracing [15,16], leading to the final predictable surprise event [17]. The Greenvale housing development in Trinidad and Tobago was chosen as the critical case study to show the project issues, societal issues, and sunk cost expenditures over time during and after project delivery. It traces the growth in cost estimates and assesses these linkages through path dependencies via: (i) decision-making through administration of the main contracts; (ii) inattention to risks during the project planning and construction phases; and (iii) the consequences of 'lock-in' on a failing course of action. Issues identified within these dependencies provide explanations for the benefits or shortfalls realised in public sector housing projects. The derived understanding prohibits transforming noble intentions into a social ill (a burden placed on society).

By examining the multiple rationalities within public housing, this research offers reinforcement to the current heated debate on the root causes of cost overruns in transport projects [18,19], i.e., political stakeholders strategically limit technical designs. This obstruction leads to 'lock-in', or the over-commitment to complete the project, knowing that it will lead to a failing course of action. Consequently, the project can be a burden to society. This research reinforces the need for project actors, especially in SIDS, to take an etic view of project design and refrain from involvement in partisan policies. Thus, an overall improvement in due diligence oversight on public funds expenditure can materialise, and project threats dismantled before their influences become systemically embedded within the project's processes, structure, and life cycle.

\section{Literature Review}

Project success research has become increasingly context-oriented, where knowledge on project performance evolved along two trajectories: success factors and success criteria [20]. Although the project environment is known to be complex and uncertain in nature [21,22], the evolution of classifications in project success criteria still narrows to the 
traditionally adopted performance metrics involving time, cost, and quality [23,24]. These metrics form the popular 'iron triangle' of project management within the PMI's framework $[25,26]$. As Atkinson [27] explains, the 'iron triangle' components of time, cost, and quality can be easily understood and measured quantitatively. Completion within budgeted sums and contracted schedules, together with minimal low impact non-conformances, indicate and promote successful project performance. Likewise, the transferability of knowledge and the ability to gather meaningful learning from projects through shared experiences are also considered 'real' success factors [28]. However, capturing the variety of learning and its nuances can be a daunting task, absorbing multiple and dedicated resources within the organisational structure. Controls such as 'lessons learned' documentation provide a mechanism to capture and log some project knowledge and experience. However, they are ineffective in capturing the environment's dynamism and the conceptualisation and execution of knowledge packets by individuals. Lycett et al. [29] refer to these lost experiences as missed opportunities to improve the effectiveness of project managers.

In public sector social development projects, it can be argued that the most important success criterion is cost accountability [2]. Through the effective and efficient use of taxpayers' dollars, projects are built to address societal needs and improve living standards [2]. In the framework of agency theory, the principal (the taxpayer) expects the government (the agent) to seek the public's benefit [30]. Effectiveness is measured by selecting projects yielding the largest possible benefits to the principal, and efficiency is determined by delivering these intended benefits within the constraints of time, cost, and quality. If effectively managed, these social development infrastructure projects can meet sustainability goals and add value to society by balancing developmental objectives without adversely impacting the environment and wellbeing of the current and future populace.

Nevertheless, the majority of the selection and execution of public projects are suboptimal, resulting in large cost overruns [12,31] and ineffective solutions in meeting taxpayers' expectations [32]. The continued inaccuracy of cost estimates of public infrastructure expenditure worldwide conjures an acceptance of cost overruns, or cost underestimation. Ultimately, an 'inverted-Darwinism' paradox [33] holds true, depicting the phenomenon of increases in demand and size of infrastructure projects as the mechanism of economic growth, despite their continued dismal performance in meeting basic success targets.

Four broad explanations are given for the causes of cost overruns due to inaccurate cost estimates. The first is that technical explanations of cost overruns are mainly associated with the unpredictability of future events affecting project execution and are mainly based on honest mistakes. Scope changes, errors in designs, omissions of design details and documentation, incomplete designs [34], and inadequate planning processes [35] are the high-ranked causes grouped under technical explanations. Secondly, economic explanations capture the causes of inefficient allocation of scarce resources to underestimate true costs. Macroeconomic conditions, such as a country's credit worthiness and global financial indicators, are other explanations that can affect a country's economic delivery. Lack of incentives, weak financing, contractual mechanisms, and strategically underestimating costs to increase a project's viability because of dedicated funding processes or self-interests are the main causes attributed to economic explanations [12].

Within political explanations of cost overruns, Wachs [36] observed that inaccuracy in forecasting in transportation projects is either based on imperfect techniques generating errors or the deliberate fitting of figures to favour political criteria over economic and technical criteria. Wachs concluded that political criteria dominated public infrastructure projects because assumptions made in forecasting are continually adjusted to favour 'politically attractive outcomes'. Cantarelli et al. [12] and Flyvbjerg et al. [18] agreed that political explanations best account for cost overruns. Deliberately manipulating cost, typically underestimating the true cost, and overestimating benefits to increase the chances that such projects are accepted, is termed strategic misrepresentation. Strategic misrepresentation can occur through organisational and political pressures, information asymmetry, and the lack of long-term commitment and discipline [37]. 
The escalation of commitment to decisions based on path dependency, resulting in ineffective actions, is termed 'lock-in' [12]. When strategic behaviours are used to favour a politically attractive project, technical and economically viable alternatives are often overlooked. This oversight was recognised by [14] as the need to justify the viability of inferior alternatives leading decision-makers to become dependent on an ineffective path of action. In so doing, sub-optimal policies are created as justification for the particular path of action. Decision-makers' commitment to the path of action increases as time elapses and more resources are invested to achieve the outcome or project objectives. Consequently, the ability to reconsider or reverse sub-optimal decisions becomes increasingly difficult.

Several indicators of lock-in, which manifest as cost overruns, were recognised in transportation infrastructure projects, and include the prevalence of sunk costs, escalating commitment, and justification without a critical assessment of alternatives. This leads to inflexibility in decision-making and the closure of alternatives [12]. In addition, political vulnerability may lead to an escalating commitment to public sector projects due to the influence of political interests and commitment to decisions, guised as policies. Therefore, the early recognition and prevention of lock-in within politically vulnerable public sector projects can reduce predictable strategic behaviours designed to deliver unintentional or intentional benefit shortfalls through sub-optimal actions (processes, policies, design requirements, and specifications). Ultimately, practices leading to lock-in can have a negative cost impact on a project and society. Table 1 proposes a theoretical framework for tracing these sub-optimal outcomes' path dependency to a theoretical concept.

Table 1. The theoretical framework for politically vulnerable projects.

\begin{tabular}{cccc}
\hline Nobel Intent & & & Social Ill \\
\hline $\begin{array}{c}\text { Theoretical } \\
\text { Concepts }\end{array}$ & Input Variables & Indicator & Outcome \\
\hline Principal-Agent & Strategic Behaviour & $\begin{array}{c}\text { Predictable surprise } \\
\text { (Wicked Problem) }\end{array}$ & Clumsy solutions \\
\hline Contract Theory & Design & $\begin{array}{c}\text { Scope changes, errors, } \\
\text { omissions }\end{array}$ & $\begin{array}{c}\text { Time overrun } \\
\text { Cost overrun } \\
\text { Legal implication }\end{array}$ \\
\hline Transaction Costs & $\begin{array}{c}\text { Political Vulnerability } \\
\text { Political Pressures } \\
\text { Sunk Costs }\end{array}$ & $\begin{array}{c}\text { Lock-in: } \\
\text {-conscious } \\
\text {-unconscious }\end{array}$ & $\begin{array}{c}\text { Benefit shortfall } \\
\text { Social injustice }\end{array}$ \\
\hline Theory of Constraints & Public Consultations & Design inadequacy & $\begin{array}{c}\text { Social pressures } \\
\text { Protests }\end{array}$ \\
\hline
\end{tabular}

Contemporary research into cost overruns mainly focuses on cost overruns causes 'as a consequence of' or symptoms associated with poor project performance [1-3]. However, further investigations into whether cost overruns continue after the completion of a project are infrequently undertaken. To address this phenomenon, we tested the theoretical concept of lock-in through a different context of public social housing projects as compared to major transport infrastructure programs. These public sector projects share fundamental similarities, such as being government-funded with private participation through contracting. However, public housing is a more personalised public good, because a beneficiary enjoys personal space and time in a housing unit and focuses on family development and entrepreneurial initiatives. This kind of project encourages social and cultural exchanges and the building of new relationships. These personal exchanges build a social network that adds unique characteristics to public housing developments, ultimately changing what was once a housing project into a vibrant community.

From the body of literature explored, the research objectives were to determine whether the emergence of cost overruns is a consequence of path dependency in decisionmaking, whether lock-in occurred, and which of the four root causes of cost overruns 
provides a better explanation for 'lock-in'. A single critical case study was selected to derive empirical evidence on the phenomena of the manifestation and causality of 'lock-in' using the following four research questions:

1. What causal factors explain the benefit shortfalls and social implications in SIDPs?;

2. Did ineffective decision-making lead to lock-in, and at what level (organisation and/or project)?;

3. Which root cause, based on the identified causal factors, provides the dominant explanation for cost overruns?;

4. What challenges and impacts, if any, does 'lock-in' present on the case study project?

\section{Research Method}

This research adopted a qualitative approach, where a critical 'case study' [38] was used to address the research questions. A critical case study was selected to investigate the causal chain of diachronic decision-making events, or lack thereof, through processtracing $[15,16]$. This critical case study methodology is advantageous in providing details through multiple sources of instruments about contemporary phenomena and decision processes using real-life contexts [39], particularly in situations where the benefit of hindsight can provide analytical inferences as compared to statistical generalisation. The selection of a single case study is self-evident replication and context-specific knowledge. The Greenvale housing development in Trinidad and Tobago was chosen as a critical research case for theoretical replication, investigating key actors, processes, and events that led to the project's failure (flooding disaster) in October 2018, and the ensuing outcry from the public throughout 2019.

Research instruments such as literature surveys and semi-formal interviews were primary and secondary data collection sources. Semi-structured telephone interviews were undertaken to explore the decision-making rationalities of the main project practitioners. All ethical protocols were observed during the administration of the semi-structured interviews. Participants were informed of the objectives of the study and the line of inquiry into cost overruns. Participants were also clearly notified that participation in the interview was non-mandatory and that they could curtail the conversation at any point in time. Conversation occurred with the client's senior project manager, who held oversight responsibilities for the project between 2009 and 2014, in November 2019. Engaging the senior project manager from 2007 to 2009 proved futile; the participant indicated an unwillingness to discuss issues on the project, and the researcher thanked the participant for his time.

Interviews through telephone conversations with the two major contractor's representatives were also undertaken, using scripted, open-ended questions. The feedback from one of the contractors was positive, and the researcher was invited to their office to engage in further discussions with the contract manager and operations manager. Data on cost, schedule, and change requests were provided for further analysis and interpretation. Open-ended questions were selected to allow the participants to express their views, perceptions, interpretations, and suggestions without any limitations. This method is suitable for gathering data from practical knowledge and building hypotheses for testing [38]. Finally, three site visits were conducted over three months in the rainy season between September and November 2019 to ascertain and observe the site layout and design contingencies, as well as to gather data from a random sample of housing beneficiaries about their interpretation of the issues which they faced within their community. Primary data were extracted from minutes of meetings, project status reports, and construction drawings. Secondary data sources heavily influenced the research and formulation of the problem statement. These sources were derived from the Parliamentary Hansard scripts, joint select committee reports, and daily newspaper articles. 


\section{Case Study: Greenvale Housing Development}

Greenvale is a public sector social housing project approved by the Government of Trinidad and Tobago in 2002. It was the final phase to complete the La Horquetta Housing Development, which commenced in 1976. The Greenvale project consists of three phases with a planned 557 housing units [40]. However, 27 of those units were not constructed due to illegal housing encroachment on the designated building site. Although designated for agricultural use and the availability of state lands in neighbouring areas, the Government, through the Ministry, purchased the land at an estimated cost of 12 million Trinidad and Tobago dollars (TTD) in 2003. Building approvals were initially rejected in 2005, but the Government decided to progress to the construction phase by procuring contractors. The mechanism of contractual selection was on a sole selected basis. Negotiations with two preferred contractors were completed in 2006, utilising the design-bid-build procurement route. Seven years after the initial contract was awarded and a schedule overrun by $250 \%$, beneficiaries of public housing were able to access Greenvale in 2014. On 20 October 2018, torrential rains caused the neighbouring river to overflow and inundate the entire area to depths of approximately $1.5 \mathrm{~m}$ [41] (Scheme 1). This inundation became a social nightmare, where families were ferried out with help from the wider population, while the Government and the opposition parties debated who was responsible for this issue. One year later, in October 2019, heavy rainfall caused panic within the community, whilst scores of residents fled the area for fear of repeated flooding $[42,43]$.

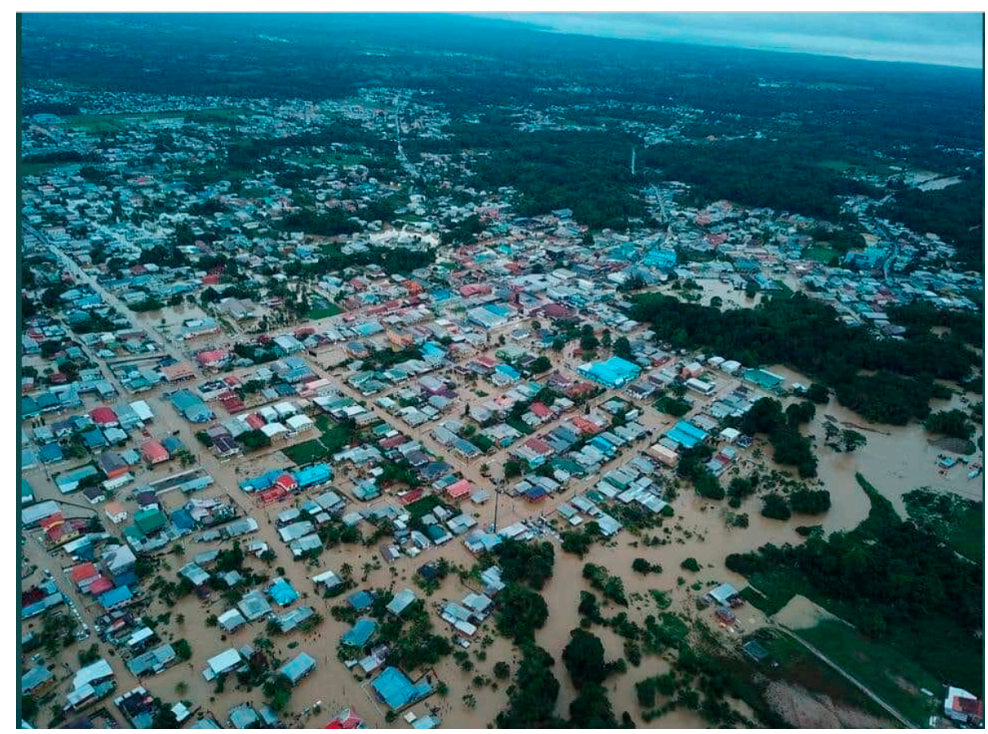

Scheme 1. Greenvale housing development inundated by flooding in October 2018 (https: / twitter. com/MothersUnion/status/1053738412052828161/photo/1, accessed on 22 January 2021).

Despite the early warning signs surrounding the dangers of constructing a housing development on the Caroni river's flood plains in Greenvale, La Horquetta, approvals and necessary procedures were bypassed [41]. The media reported that engineers, consultants, and decision-makers could not predict the 14 inches of rainfall experienced within just two days during the October 2018 rainy season [42]. The project's professionals were optimistic that mitigation strategies, such as retention ponds, maintenance of flood pumps, and clearing of the river path, were enough to prevent flooding within the Greenvale area. In the end, an intended beneficial project cost the taxpayers of Trinidad and Tobago over TTD 63,030,000 in damage repairs and compensation, with a potential lawsuit [43]. Maraj [44] recalled the Greenvale flooding incident where those trapped were rescued by members within their community while awaiting assistance from the Ministry of National Security. This neglect led citizens to question the preparedness response of the Office of 
Disaster Preparedness and Management (ODPM), because they believed it was the culture of the system not to be prepared for such unexpected disasters [45].

Unfortunately, annual flooding was not an unknown event to the area; prior drainage designs submitted by the consultant were rejected and drainage approval refused, because the area was deemed a low-lying, flood-prone area [43]. This predictable surprise resulted in a further TTD 63 million being spent by the Government to repair the existing housing stock and insurance agencies refusing to grant insurance due to the initial and obvious client breaches. Figures 1 and 2 summarise the timeline of major events, from the initial decision to build in 2002 to the flooding event in 2018.

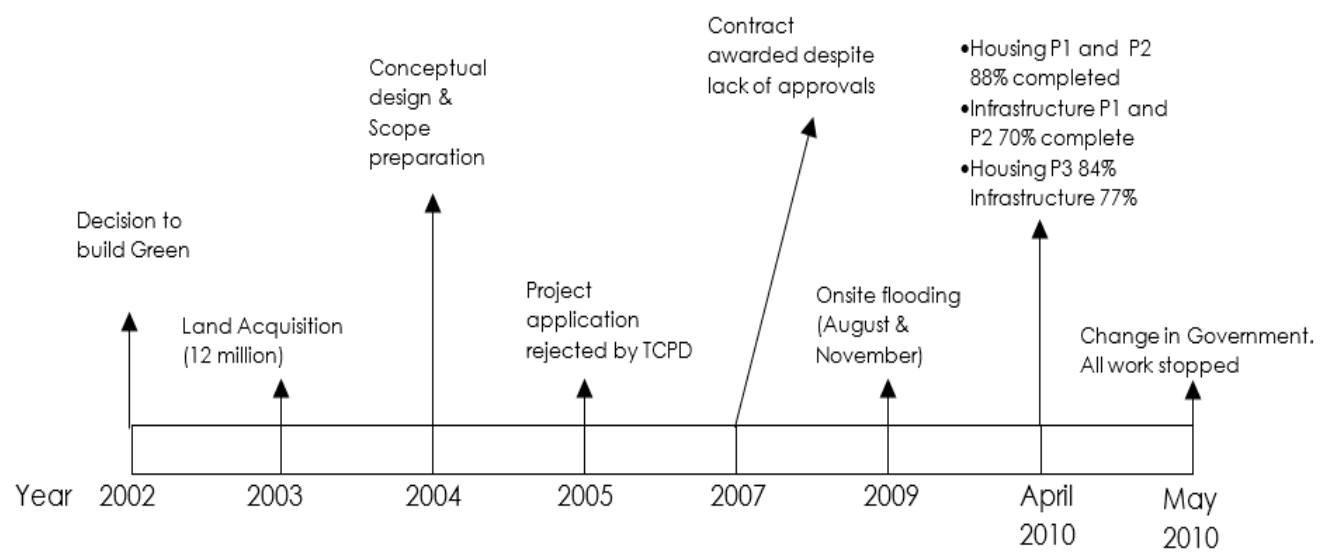

Figure 1. Timeline 1 for Greenvale (project level) during the period 2002-2010.

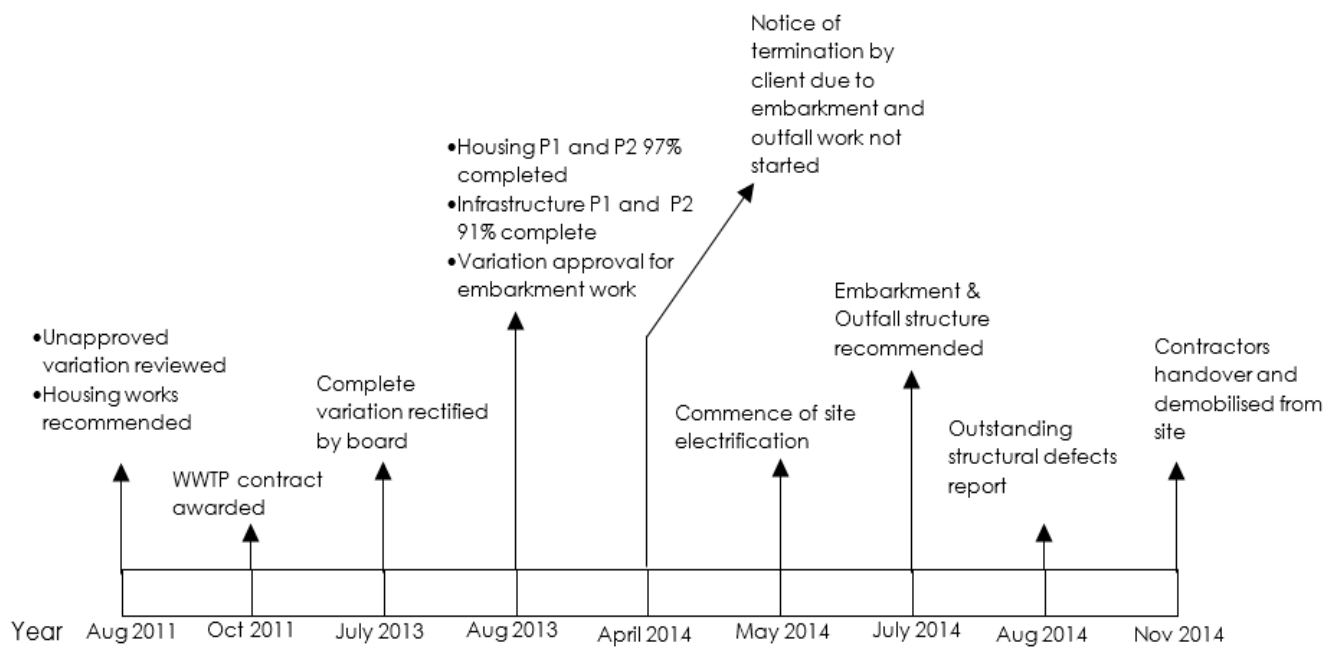

Figure 2. Timeline 2 for the period August 2011-November 2014.

\section{Findings}

A variety of construction contracts, both standard form and bespoke formats, were employed on this project, creating further complexities in the use and enforcement of these varying contractual requirements. Thus, further investigation into the applicability, consistency, and understanding behind each type of contract is warranted.

\subsection{Housing Contractual Arrangement}

In 2007, Contractor 1 was awarded an initial contract amount of TTD 137 million under a bespoke joint venture contract agreement. This form of contract was not in congruence with the general standardised form typically specific to the Client/Contractor's relationship. The bespoke joint venture contract, drafted by in-house legal professionals, was tailored 
to suit the organisation's needs and project-related requirements. A similar bespoke agreement was awarded to Contractor 2 in 2008, although work commenced in 2007, for approximately TTD 97.5 million.

It was found that the bespoke contract formulated for the housing component of the project proved relatively effective in managing cost overruns. The final contract price for Contractor 1 overran by $16.7 \%$ over a seven-year period. This variation was mainly due to additional finishes (i.e., tiling) to the unit and inflationary pressures. The contract price for Contractor 2 overran by $5.8 \%$ above the original contract awarded for similar variation work.

\subsection{Infrastructure Contractual Arrangement}

Infrastructure work contracts were awarded independently from the housing contracts. This was viewed from a risk management perspective to independently manage costs because infrastructure designs were not fully developed and approved. A Fédération Internationale des Ingénieurs-Conseils (FIDIC 1999) short form standard contract, typically referred to as 'the Green Book', was adopted as the preferred standard form contracting mechanism. The FIDIC short form of contracting (Green Book) is normally recommended for simple and repetitive construction work between the client and the contractor, with a relatively short duration and smaller contracting sums [17], typically up to USD 500,000 or approximately TTD 3,150,000 at the 2007 exchange rate. It also removes the legal conditions requiring an independent engineer to administer the contract.

Contractor 1 was awarded an infrastructure contract for two of the three phases for an initial contract sum of approximately TTD 29,100,000.00 (TTD 13,300,000 for phase 1 and TTD 15,800,000 for phase 2). Another contract of TTD 9,365,000.00 was awarded for embarkment work. No design responsibilities were given to Contractor 1. Variations during the seven-year period amounted to TTD $28,340,000$, or $97 \%$ above the original contract amount. The embarkment contract was not completed due to the presence of squatters, resulting in a reduction of TTD 200,000 from the original contract amount.

Contractor 2 was officially awarded an infrastructure contract of TTD 13,720,000 in January 2010. This award was three years after their initial housing contract, when construction of all building units was substantially completed. The consultant subsequently approved an additional TTD 26,793,000 in variation work within the same year, a 197\% variation above the original contract price. The main reasons cited for the infrastructure increase were redesigning and reworking the drainage, sewer, roads, and plumbing network.

In 2012, a separate contract was awarded for wastewater treatment (TTD 8,451,000 with a variation of TTD 1,046,000). The procurement method was the FIDIC design and build standard form contract (FIDIC's Yellow Book), awarded to a specialist wastewater contractor. This work suffered a delay of five weeks due to inclement weather, soil slippages, and stabilisation due to the existing high groundwater table. Variation granted in this contract amounted to an approximately $12.5 \%$ cost overrun.

\subsection{Design Issues}

The failures by the major stakeholders (client, contractors, and consultants) to recognise and prioritise uncertainties, such as the elevation of housing units above the flood zone, shifted a controllable risk (elevation) to an uncontrollable risk (i.e., flooding). Ignoring the concerns expressed by the Ministry's Drainage Division from the initial design submission in 2005, the entire development became a flooding hazard during intense seasonal rainfall events. The client relied on the consultant's design recommendations that detention ponds could be constructed to manage the runoff, despite the lack of hydrologic and hydraulic analyses. In the absence of designs, scope and budget requirements were ill-conceived. Design errors ultimately manifested as work which commenced prior to formal approval by the client. During excavation of the detention pond, the design overlooked the high water table in this area. The detention pond's resulting design capacity was substantially reduced, rendering the storage capacity inadequate to control and store designed runoff 
events. Figure 3 depicts the above sequence of events of consciously locking-in the project by ignoring early warnings from regulators, leading to a predictable surprise [17] and ultimately, cost overruns.

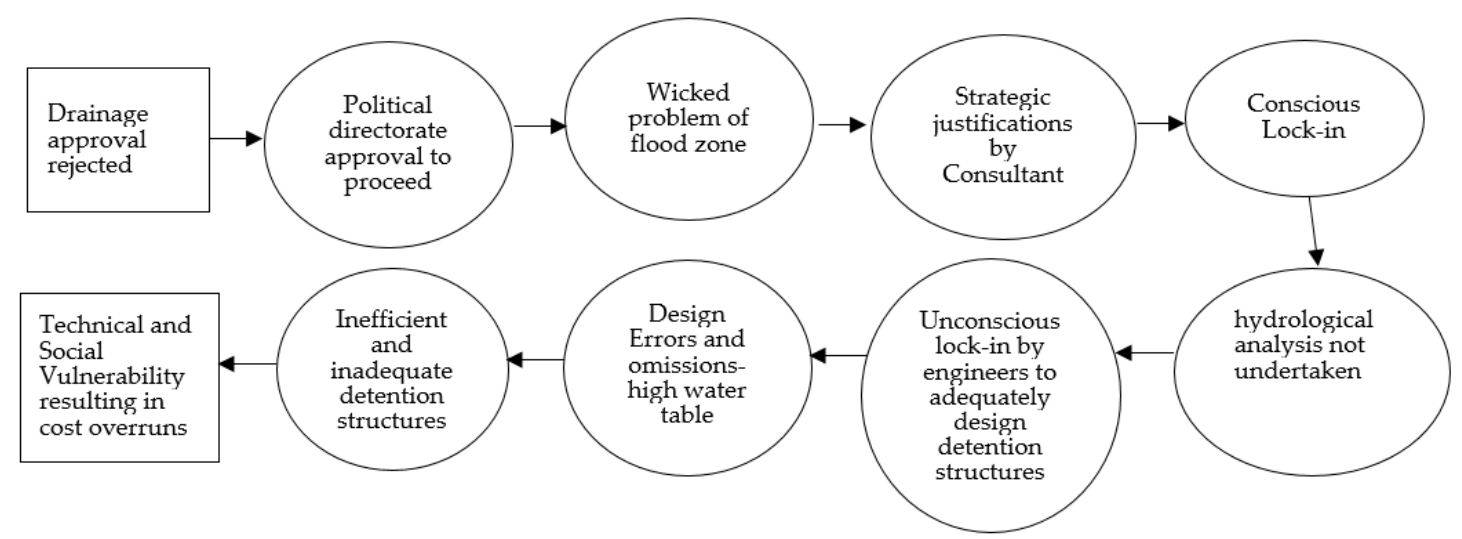

Figure 3. Ineffective decisions creating technical vulnerabilities and cost overruns.

\subsection{Final Project Construction Costs}

The total contracted cost for infrastructure and housing development, excluding transactional cost, was approximated to TTD 277,320,000. Supplementary contracts and variations were duly granted for additional work and rework, amounting to approximately TTD 94,800,000. The overall final estimated construction cost of TTD 372,000,000 represents an approximate $40 \%$ cost overrun on the project. This overrun excludes roadworks and other utility costs to the Ministry of Works, and the capital costs paid for the land.

Due to the limited applicability of the FIDIC short-form contracts on large infrastructure projects, the applicability of the Green Book as both a contractual and control tool proved highly ineffective when considering that the average cost overruns on infrastructure contracts was $147 \%$ beyond the initial contract sum. This view was also confirmed and held by the client's project manager, who possessed both legal and engineering postgraduate qualifications, with 30 years of experience administering contracts. The use of the Green Book as the form of contract for infrastructure work was viewed as an anomaly within the organisation, because FIDIC's Red (design-bid-build) and Yellow (design-build) books were adopted by other housing and infrastructure project within the same housing program. Although the Green Book effectively removes the engineer's role, the same consultant was contracted to administer the engineer's responsibilities based on a percentage of the final contract sum.

\section{Discussion}

The decision-making process for adopting varying contractual mechanisms, i.e., path dependency due to political influences, played a role in locking-in the project to an ineffective outcome. Contractor's 1 view was that the Green Book allows flexibility to execute work in a modular approach while the consultant is finalising designs. The client's senior manager expressed a strong contradicting view on utilising FIDIC's short-form contracting instead of FIDIC's design and build contracts (Yellow Book). The organisation's decisionmakers ignored this recommendation. Contrary to sound technical advice, the award of the infrastructure contract to Contractor 2 in 2010 included an additional responsibility to design the infrastructure. Therefore, procurement mechanisms have a direct effect on managing the outcome of cost overruns on a contract.

The plausibility of strategic and intentionally erroneous application of ineffective standard form contracting formats on this project cannot be ruled out; no other housing projects within the same programme utilised short form contracting for infrastructure projects [2]. Explanations of oversight, optimism, and lack of expertise cannot hold when 
sound appropriate technical and procurement advice are issued by the client's project manager. Strategic misrepresentation can offer a better explanation [30]. In the government's quest to promote affordable social housing, a policy was adopted in 2006 to subsidise all infrastructure development costs. The subsidising of infrastructure had a direct agency effect. The strategic use of an inadequate procurement model for infrastructure work resulted in less rigorous contractual control. Infrastructure costs were not reflected in public sector housing pricing and, consequently, were invisible to public scrutiny. Change order documentation revealed that these large variations and claims were presented and justified in 2010, before oversight by the newly installed board of decision-makers. The consultant's legitimacy to knowingly recommend these inferior infrastructure contracts came under further scrutiny when the consultant bypassed the reporting protocol of review and authorisation by the client's senior manager before obtaining final approval.

Cost overruns of $97 \%$ and $197 \%$ on infrastructure contracts between the two main contractors on site, as compared to $16.7 \%$ and $5.8 \%$ overruns on housing contracts, indicate an inverse correlation between cost overruns and perceived accountability. Contracts issued for the housing component of the work are visible to public scrutiny and greater accountability. Thus, their cost overruns were within manageable and controllable limits. A reasonable assumption is that all technical issues should have been captured if designers and planners were compliant with proper planning and design processes. As such, causes for this exponential growth of cost overruns in infrastructure projects lie beyond technical explanations, although technical reasons were used to justify and resolve the problems associated with flooding. Unfortunately, to date, infrastructure work has fallen tremendously short on resolving the problem of flooding. An alternative explanation may be found within behavioural sciences; mainly strategic behaviour, due to the project's political vulnerability.

From the exponential cost growth in infrastructure contracts, a scenario explored was whether these contracts were intentionally designed to fail to justify costs. Housing contracts are visible to the public because housing prices are derived from actual construction costs. However, for low-income beneficiaries, the costs associated with infrastructure projects are fully subsidised by the Government. These costs are not included in the sale of housing units, and therefore these contracts are not highly visible for public scrutiny as compared to housing contracts. It is not a chance scenario that housing contracts fall within contingency margins typically attributed to errors and omissions in designs within a normal standard distribution. In the same perspective, it is not a chance scenario that infrastructure contracts were administered using an inadequate and ineffective system and different from the standard practice.

Questionable practices were also emanated through the award of variation work to both contractors and approved by the consultant without formal authorisation by the client. This work commenced during the election cycle in 2010, 'locking-in' the client to pay for these approved works. Unfortunately, major projects such as embarkment protection, awarded in 2007, stopped at 48\%, allowing flood to ingress onto the site in 2009 and 2010. Thereafter, the issue of flooding was used to justify the need for additional work. Due to these floods, a further variation was awarded in 2013 to clean and remediate existing infrastructure projects where siltation accumulated from floodwaters. Thus, conscious lock-in was created based on strategic opportunities to maximise variation costs.

From a technical lens, a derivation of an approximate cost to raise 557 units 5 feet higher, using the quantity surveyor's 2010 rates and adjusted for a technical cost overrun of $15 \%$, would have cost TTD 13 million or TTD 23,340 per unit. This could not have been undertaken, because all housing work was $88 \%$ completed when infrastructure work commenced. The remaining $12 \%$ was due to the completion of connectivity to electrical, sewer and plumbing infrastructure, which were all unavailable in 2010. The completion of housing before infrastructure had the effect of 'locking-in' any successive governments to complete the project. The implication to the government's policy is the dilemma of whether to abandon houses $90 \%$ completed and TTD 240 million of taxpayers' money sunk into this 
project, while the demand for public housing continues to grow. The government's logical step was to complete the development, investigate the legitimacy of the variation work, and minimise further legal obligations brought forward by the contractors.

\subsection{Practical Implications of 'Lock-in' on the Public Sector}

The flooding of Greenvale Housing Development in 2018 was a consequence of a natural storm event within a low-lying region. Current mitigative strategies by disaster preparedness personnel and community organisations brought temporary relief, but floods could not have been prevented. Neighbouring low-lying communities were also adversely affected. However, to discount the calamity of such disastrous events that should have been identified and incorporated into planning and risk strategies is being either overly optimistic or outright careless. Clearly, the occurrence of this natural disaster event was foreseeable, because the Caribbean's weather pattern is a seasonal event: the first half of the year is the dry season; and the second half, the wet season, is typically accompanied by annual heavy storm events. The repetitive and cyclic patterns of these seasonal events increase the probability of foreseeability or predictability of such storm events. The presence of both elements of foreseeability and predictability of storm events shifts accountability to the fitness of purpose of this social housing development and the lack of preventative responses in 2018 on its agents.

Watkins and Bazerman [17] defined such disastrous events as a predictable surprise, i.e., being affected by a foreseeable or predictable event that should have been accounted for during planning. Political, organisational, and psychological barriers typically hinder an organisation's preparedness to react to predictable surprises. Applying Watkins and Bazerman's three barriers to the case study [46], the political barrier manifested through strategic misrepresentation, creating a path dependency that 'locked-in' costs on the project. After five building approval rejections and a clear indication from the drainage authorities that these lands' development will further contribute to flooding [43], the political directorate approved construction work at this particular location.

The psychological barrier materialised as the need to justify technical solutions through analytical techniques via design and technical analyses. Another element supporting the psychological barrier was the optimism bias within the project team that proposed technical solutions would eliminate the problem of flooding. The third barrier was traced to the organisation's inability to effectively address and eliminate the problem at the beginning of the project. Detailed planning and risk management strategies to better control the effects of the disaster during the implementation stages are pre-requisites before commencing housing construction. The haste to construct housing without requisite approvals, procedures, and documentation did little to justify the need to satisfy housing demand politically. Consequently, approximately TTD 63,000,000 additional funding had to be spent by the state to remediate flood-affected units. This cost continued to grow because of the initial decision locking in all parties to construct affordable housing units in a known flood plain without improving the development's elevations.

\subsection{Theoretical Implication of 'Lock-in'}

These findings demonstrate that the cost implications of 'lock-in' continued after project completion and commissioning, and manifest as high maintenance and repair costs. The modifications to the 'lock-in' theoretical constructs are represented in Figure 4. 


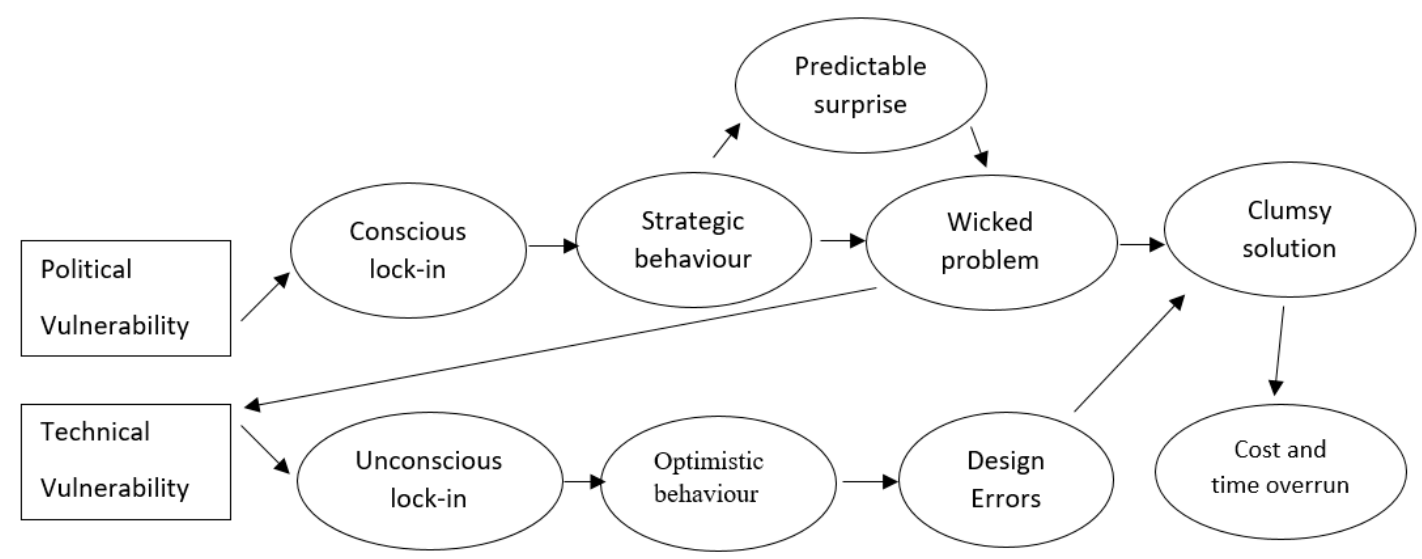

Figure 4. Inefficient decision-making pathway throughout the project life cycle based on the lock-in concept.

Strategic behaviours were continued by key decision-makers (executive management and consultants) on infrastructure projects that required justification for additional expenditure arising from incomplete infrastructure designs and the application of a variety of ineffective contractual agreements [11]. Furthermore, constructing houses before an acceptable level of completion of infrastructure and utility work created a 'point of no return' [11]. Thus, between 2003 and 2010, political vulnerability and strategic misrepresentation were plausible explanations for lock-in, contributing to inefficient decision-making and cost overruns.

Abandonment of projects plagued with negative societal consequences is one viable option, but sunk costs, closure of alternatives, and political pressures can prevent such a decision. Politically, abandoning the project would have created the need to justify to the public the mismanagement of taxpayers' dollars by the previous administration. Socially, the demand for housing far overshadows the supply and continues to increase. Security would also be required to prevent illegal tenancy and other criminal activities. Environmentally, this once-natural landscape could become a breeding ground for pests; bats, rodents, and insects, for example. Economically, hundreds of millions of dollars were already sunk in this project, with housing at $88 \%$ completion. Decision-making at the newly installed cabinet and management levels in 2010 was locked in to find plausible technical solutions to complete the remaining $12 \%$ of the housing component of the project.

The new team's customer-focused culture focused on beneficiaries' welfare and the organisation's core values to provide the basic need for sustainable and affordable housing. Existing consultants and contractors were retained to reduce the knowledge gap, but a new client senior project manager was hired to provide due diligence and oversight support. The team was highly optimistic about completing this project using modified technical solutions. Optimism prevailed on the technical measures proposed to counter flooding, such as completing an embankment around the development, installing automated flap gates at the outfall, a larger internal drainage network, and retention ponds. It was also recognised as a contingency that the development required regular maintenance. Thus, a maintenance programme was developed for outfall structures and the main watercourses for the speedy removal of storm waters. Additional maintenance strategies were created to this effect, further adding to the escalating unaccounted costs on the taxpayers for this project.

\subsection{Challenges to 'Lock-in' Treatments}

Lock-in presents several challenges in assessing both culpability and liability for the continued social ill of a failed affordable housing project. The recognition of flood plain land and approximately sixty squatters encumbering the transfer of title of the lands were early warning indicators. However, managing these complicated environmental and social issues were delayed to the construction phase rather than being addressed before acquiring 
these lands for housing. Strategic opportunities because of political pressures created escalating commitment and lock-in before actual project conceptualisation. This can be seen via the decision-making processes' inflexibility to consider alternatives and utilise these lands for other approved purposes.

Politically vulnerable projects are exposed to deceptive practices permeating throughout the lifecycle of the project. Project managers cannot control the effects of deceptive practices such as abuse of power, fraud, embezzlement, conflict of interests and nepotism [47-50]. Such ill-conceived practices on public sector housing projects occur when agents misuse their public power to mismanage taxpayers' funds for favourable gains [50], which is akin to corruption. Such practices in abusing entrusted power [51] are done at the expense of the project's performances, resulting in delays, cost overrun, and compromised quality. Lock-in emanating from deceptive practices harms society. It costs citizens their safety, health, finances, and even their lives. The effects of lock-in continue after the completion of public construction projects. Every stakeholder has a role in ensuring that due diligence mechanisms are implemented for public expenditure on these social initiatives through accountable and transparent practices [51].

\section{Conclusions}

In this study, we explored the emergence and influence of lock-in leading to negative outcomes in public-sector housing projects. The case study adopted a critical realist philosophical lens to provide insights into the relationships among political rationalities, managerial decision-making, and cost performances in politically vulnerable projects such as social housing development. The method of process tracing was used to address causality by analysing the chain of decision-making events. The case study demonstrates that strategic opportunities arose due to political pressures, resulting in escalating commitment which led to lock-in before actual project conceptualisation was completed.

Political influences, rather than technical factors, were the dominant root cause of cost overruns. While both optimism and strategic behaviour are significant predictors of cost overruns, this case study demonstrated that inadequate designs and cost underestimation were caused by political influence, manifesting as cost overruns during the construction phase. Although initial restrictions on the location and usage for social housing were based on political considerations, if technical requirements and designs for infrastructure are substantially completed and diligently followed before housing construction began, such practice can reduce a project's political vulnerability.

In addition, predictable surprises such as flooding disasters and the consequential social anguish and public concern for residents living in such developments are preventable. As a result of the presence of both elements of foreseeability and predictability of storm events, accountability shifts to the fitness of purpose for social housing development. This commitment can be seen in the inflexibility of decision-making processes to consider improved technical and feasible alternatives. If lock-in can be identified and addressed before project implementation, problems associated with managerial decision-making can be eliminated, and consequently, the cost overrun phenomenon will be significantly reduced.

Political root cause was found to be the dominant explanation for cost overruns. Projects will follow the lesser optimal path for political expediency in lieu of planned technical determinacy and project temporality. The political root cause of cost overrun took the form of strategic misrepresentation, which creates a path dependency that 'locks in' project decisions and costs. Consultants and technocrats were willing to forego fundamental systematic technical inquiry expected in the planning and design phases of a project to comply with unsound assertions for political partisanship. The outcomes are the creation of incomplete and unjustified design drawings and specifications. Downstream, the project team subsumes the task to create synergies among incomplete designs, project documentation and constructability during the construction phase. Thereafter, the psychological barrier manifested as the optimistic need to justify knowingly inefficient technical solutions using design analytical techniques. Suboptimal progress paths created out of political 
vulnerability increase the escalation of commitment to ineffective decision-making until a point of no return is reached, indicating the presence, strength, and danger of lock-in. Thus, in an attempt to develop optimal solutions given suboptimal decisions, inferior solutions and outcomes materialised.

Challenges and impacts that lock-in presented on the project were the intentional creation of mundane and incomplete artefacts (designs, specifications, documentations) that affected managerial capabilities at both the project and organisation level. The case study showed that cost overruns were not extinguished upon completion of the project's commissioning phase, but continued in the user/operation phase as increases in annual expenditure for maintenance, government grants and assistance programs, and transaction costs for mitigation efforts. These types of costs are associated with the lock-in phenomenon and are a subject for future research.

Previous literature has investigated lock-in within the initial phases of project delivery in a typical project life cycle. However, this work expands the theoretical concept beyond the construction and commissioning phases (initial phases) to demonstrate the phenomenon manifested in the user/operation phase (final phase) of a social housing infrastructure project. The research is meant to unearth and uncover strategic practices that allow policymakers and technocrats to witness the adverse consequences of their actions on the general populace, which, if heeded, allow them to make better-informed policy decisions when it comes to a social infrastructure project. We also acknowledge that the limitation of this critical case study results are context-specific to geography or macroeconomic conditions. As such, the results may not be generalisable. Future studies and independent investigations into different SIDS can be undertaken to uncover and generalise the lock-in phenomenon.

Author Contributions: Conceptualisation, A.A.C.; Methodology, A.A.C.; Validation, A.A.C.; Formal Analysis, A.A.C. and H.H.M.; Resources, A.A.C. and X.T.C.; Data Curation, A.A.C.; Writing-Original Draft Preparation, A.A.C.; Writing-Review and Editing, A.A.C., X.T.C. and H.H.M.; Visualisation, A.A.C.; Supervision, A.M.; Project Administration, A.A.C. All authors have read and agreed to the published version of the manuscript.

Funding: This research received no external funding.

Institutional Review Board Statement: Not applicable.

Informed Consent Statement: Informed consent was obtained from all subjects involved in the study.

Data Availability Statement: The data presented in this study are available on request from the corresponding author. The data are not publicly available due to privacy issues.

Acknowledgments: This study forms part of a Ph.D. study into a new theoretical discourse in managing cost overruns for social housing programmes.

Conflicts of Interest: The authors declare no conflict of interest.

\section{References}

1. Asiedu, R.O.; Adaku, E. Cost overruns of public sector construction projects: A developing country perspective. Int. J. Manag. Proj. Bus. 2019, 13, 66-84. [CrossRef]

2. Chadee, A.; Ray, I.; Chadee, X. Systemic Issues Influencing Technical Certainty in Social Housing Programmes in a Small Island Developing State. Build 2021, 11, 65. [CrossRef]

3. Amoatey, C.T.; Ameyaw, Y.A.; Adaku, E.; Famiyeh, S. Analysing delay causes and effects in Ghanaian state housing construction projects. Int. J. Manag. Proj. Bus. 2015, 8, 198-214. [CrossRef]

4. Briguglio, L. Small island developing states and their economic vulnerabilities. World Dev. 1995, 23, 1615-1632. [CrossRef]

5. Mycoo, M.; Donovan, M.G. A Blue Urban Agenda: Adapting to Climate Change in the Coastal Cities of Caribbean and Pacific Small Island Developing States. In A Blue Urban Agenda: Adapting to Climate Change in the Coastal Cities of Caribbean and Pacific Small Island Developing States; Inter-American Development Bank: Washington, DC, USA, 2017.

6. Tierney, P. Climate and Post-shock Concessional Finance in SIDS: Contributing to Resilience of Small Island Developing States; Office of the High Representative for the Least Developed: New York, NY, USA, 2018.

7. Petzold, J.; Magnan, A.K. Climate change: Thinking small islands beyond Small Island Developing States (SIDS). Clim. Chang. 2019, 152, 145-165. [CrossRef] 
8. Mycoo, M.A. A Caribbean New Urban Agenda post-Habitat III: Closing the gaps. Habitat Int. 2017, 69, 68-77. [CrossRef]

9. McHardy, P.; Donovan, M.G. The State of Social Housing in Six Caribbean Countries; Inter-American Development Bank: Washington, DC, USA, 2016.

10. Uff, J.; Thornhill, D. Report of the Commission of Enquiry into the Construction Sector Trinidad and Tobago; Ministry of Finance: Port of Spain, Trinidad and Tobago, 2010.

11. Cantarelli, C.C. Cost Overruns in Large-Scale Transport Infrastructure Projects: A Theoretical and Empirical Exploration for the Netherlands and Worldwide. Doctoral Thesis, Delft University of Technology, Delft, The Netherlands, 2011.

12. Cantarelli, C.C.; Flyvbjerg, B.; Van Wee, B.; Molin, E.J.E. Lock-in and its influence on the project performance of large-scale transportation infrastructure projects: Investigating the way in which lock-in can emerge and affect cost overruns. Environ. Plan. B Plan. Des. 2010, 37, 792-807. [CrossRef]

13. Hetemi, E.; Mere, J.O.; Nuur, C.; Engwall, M. Exploring mechanisms underlying lock-in in large infrastructure projects: A management perspective. Procedia Comput. Sci. 2017, 121, 681-691. [CrossRef]

14. Staw, B.M. The Escalation of Commitment to a Course of Action. Acad. Manag. Rev. 1981, 6, 577. [CrossRef]

15. George, A.L.; McKeown, T.J. Case studies and theories of organizational decision making. Adv. Inf. Process. Organ. 1985, 2, 21-58.

16. Jennings, W. Why costs overrun: Risk, optimism and uncertainty in budgeting for the London 2012 Olympic Games. Constr. Manag. Econ. 2012, 30, 455-462. [CrossRef]

17. Watkins, M.; Bazerman, M. Predictable Surprises: The Disasters You Should Have Seen Coming. Harv. Bus. Rev. 2003, 81, 72-85.

18. Flyvbjerg, B.; Ansar, A.; Budzier, A.; Buhl, S.; Cantarelli, C.; Garbuio, M.; Glenting, C.; Holm, M.S.; Lovallo, D.; Lunn, D. Five things you should know about cost overrun. Transp. Res. Part A Policy Pract. 2018, 118, 174-190. [CrossRef]

19. Love, P.E.; Ika, L.A.; Ahiaga-Dagbui, D.D. On de-bunking 'fake news' in a post truth era: Why does the Planning Fallacy explanation for cost overruns fall short? Transp. Res. Part. A Policy Pract. 2019, 126, 397-408. [CrossRef]

20. Moradi, S.; Kähkönen, K.; Aaltonen, K. From Past to Present- the Development of Project Success Research. J. Mod. Proj. Manag. 2020, 8. [CrossRef]

21. Love, P.E.; Ahiaga-Dagbui, D.D.; Irani, Z. Cost overruns in transportation infrastructure projects: Sowing the seeds for a probabilistic theory of causation. Transp. Res. Part. A Policy Pract. 2016, 92, 184-194. [CrossRef]

22. van Marrewijk, A.; Clegg, S.R.; Pitsis, T.S.; Veenswijk, M. Managing public-private megaprojects: Paradoxes, complexity, and project design. Int. J. Proj. Manag. 2008, 26, 591-600. [CrossRef]

23. Olsen, R.P. Can Project Management Be Defined? Proj. Manag. Q. 1971, 2, 12-14.

24. Morris, P.W.; Hough, G.H. The Anatomy of Major Projects: A Study of the Reality of Project Management; John Wiley and Sons: Chichester, UK, 1987.

25. Caccamese, A.; Bragantini, D. Beyond the Iron Triangle. Year One; PM World Journal: Addison, TX, USA, 2013.

26. PMI. A Guide to the Project Management Body of Knowledge (PMBOK Guide), 6th ed.; Project Management Institute: Newton Square, PA, USA, 2017.

27. Atkinson, R. Project management: Cost, time and quality, two best guesses and a phenomenon, its time to accept other success criteria. Int. J. Proj. Manag. 1999, 17, 337-342. [CrossRef]

28. Cooke-Davies, T. The "real" success factors on projects. Int. J. Proj. Manag. 2002, 20, 185-190. [CrossRef]

29. Lycett, M.; Rassau, A.; Danson, J. Programme management: A critical review. Int. J. Proj. Manag. 2004, 22, 289-299. [CrossRef]

30. Flyvbjerg, B. Quality control and due diligence in project management: Getting decisions right by taking the outside view. Int. J. Proj. Manag. 2013, 31, 760-774. [CrossRef]

31. Merewitz, L. How do Urban Rapid Transit Projects Compare in Cost Estimating Experience; Institute of Urban \& Regional Devel-opment, University of California: Berkeley, CA, USA, 1973.

32. Flyvbjerg, B.; Denzin, N.K.; Lincoln, Y.S. The Sage Handbook of Qualitative Research; Sage: Thousand Oaks, CA, USA, 2011; Volume 4, pp. 301-316.

33. Flyvbjerg, B. Delusions of success: Comment on Dan Lovallo and Daniel Kahneman. Harv. Bus. Rev. 2003, 81, 121-122.

34. Love, P. Plugging the Gaps' Between Optimum Bias and Strategic Misrepresentation and Infrastructure Cost Overruns. Procedia Eng. 2011, 14, 1197-1204. [CrossRef]

35. Pickrell, D.H. A Desire Named Streetcar Fantasy and Fact in Rail Transit Planning. J. Am. Plan. Assoc. 1992, 58, 158-176. [CrossRef]

36. Wachs, M. When planners lie with numbers. American Planning Association. J. Am. Plan. Assoc. 1989, $55,476$.

37. Cantarelli, C.; Molin, E.J.E.; Van Wee, B.; Flyvbjerg, B. Characteristics of cost overruns for Dutch transport infrastructure projects and the importance of the decision to build and project phases. Transp. Policy 2012, 22, 49-56. [CrossRef]

38. Flyvbjerg, B. Five Misunderstandings About Case-Study Research. Qual. Inq. 2006, 12, 219-245. [CrossRef]

39. Love, P.E.; Holt, G.D.; Li, H. Triangulation in construction management research. Eng. Constr. Archit. Manag. $2002,9,294-303$.

40. Singh, R. HDC Projects Hit by Approval Woes, Defects Mistakes Cost 2.4 billion. Trinidad and Tobago Guardian 2018. Available online: https: / www.guardian.co.tt/news/hdc-projects-hit-by-approval-woes-defects-6.2.707500.e93fc2cfb5 (accessed on 5 December 2020).

41. Davies, R. Trinidad-Hundreds displaced by Floods- Floodlist. Available online: http:/ floodlist.com/america/trinidad-floodsoctober-2018 (accessed on 3 February 2021).

42. Desilva, R. Sinanan Tours Caroni River Today. Trinidad and Tobago Guardian 2018. Available online: https://www.guardian.co. tt/news/sinanan-tours-caroni-river-tomorrow-6.2.703722.9dd5d0af8a (accessed on 5 October 2020). 
43. Vende, J.L. Greenvale Residents Unhappy with Treatment after Floods. Newsday. Available online: https://newsday.co.tt/2019 /11/27/greenvale-residents-take-hdc-to-court-over-flooding/ (accessed on 6 February 2021).

44. Maraj, R. Jammin' Still? Sunday Express 28/10/2018, 2018, p. 15. Available online: https://trinidadexpress.com/opinion/ columnists/jammin-still/article_41772950-da4a-11e8-b6a3-13ef17f28024.html (accessed on 22 January 2021).

45. Chen, Y.; Wang, W.; Zhang, S.; You, J. Understanding the multiple functions of construction contracts: The anatomy of FIDIC model contracts. Constr. Manag. Econ. 2018, 36, 472-485. [CrossRef]

46. Locatelli, G.; Mariani, G.; Sainati, T.; Greco, M. Corruption in public projects and megaprojects: There is an elephant in the room! Int. J. Proj. Manag. 2017, 35, 252-268. [CrossRef]

47. Anti-Corruption Resource Centre. Glossary. Available online: http:/ / www.u4.no/glossary/ (accessed on 12 July 2019).

48. GIACC. What Is Corruption. Available online: http://www.giaccentre.org/what_is_corruption.php (accessed on 5 December 2020).

49. Sohail, M.; Cavill, S. Accountability to Prevent Corruption in Construction Projects. J. Constr. Eng. Manag. 2008, 134, 729-738. [CrossRef]

50. Transparency International. FAQS on Corruption. Available online: https:/ /www.transparency.org/whoweare/organisation/ faqs_on_corruption/2/ (accessed on 12 July 2019).

51. Tabish, S.Z.S.; Jha, K.N. Beyond the Iron Triangle in Public Construction Projects. J. Constr. Eng. Manag. 2018, $144,04018067$. [CrossRef] 